\title{
THE EFFECT OF LOCATION ON THE VALUE OF COMMERCIAL PROPERTY IN, ONITSHA NORTH LOCAL GOVERNMENT AREA ANAMBRA STATE OF NIGERIA
}

\author{
Emenike Kingsley Chikwuado, \\ Department Of Estate Management and Valuation Dean School Of School Of Environmental Design And \\ Technology, Akanu - Ibiam Federal Polytechnic Uwana, Ebonyi State. \\ Nigeria West Africa. \\ Aka Iduma Ibiam, \\ Department Of Estate Management and Valuation Dean School Of School Of Environmental Design And \\ Technology, Akanu - Ibiam Federal Polytechnic Uwana, Ebonyi State. \\ Nigeria West Africa. \\ Ezeudu Christian Uchenna, \\ Department Of Estate Management and Valuation Dean School Of School Of Environmental Design And \\ Technology, Federal Polytechnic Oko, Anambra State, Nigeria West Africa.
}

\begin{abstract}
Location of land and landed property is a preferred choice for both occupiers as well as property owners; this is believed because there are certain considerations such as accessibility, type of property, forces of demand and supply, use of property, government policies and nearness to transport terminus. Nevertheless the study was carried out, on careful appraisal to ascertain the latent effect location has on the value of commercial property in Onitsha north local government area, anambra state. The researchers set some objectives. The findings of this study discovered that some important factors like infrastructure and facilities can make a commercial property attractive or unattractive and in so doing affects the location potentials. The study also reveals that the combination of location and needed infrastructural facilities are the key factors that influence demand and supply in real property market in the study area. The study achieve its selected objective through questionnaires the data obtain where analyze through relative important index (RII), percentage, mode, mean, with the use of satis-excel software and maps from goggle earth. The second discovery is a contribution to knowledge in the field of estate surveying and valuation profession.
\end{abstract}

Key words: Effect, Location, property Value, Commercial Property,

\section{INTRODUCTION}

As urbanization increase, the level of growth, income and taste also changes with the trend and technology. This is because every day poses with new technicalities which eliminate obsolete modalities and introduce smart and economic approaches to solving human problem in relation to cost time and quality. Careful study has reveal that investors chooses an investment that attract patronage and at the same time yields returns on investment. Which in turn arouse a need for location that has comparative economic advantage over other landuse. [1] (Okeke, 2009).

[2] Toivonen and Viitanen (2016) underlined that commercial property market is closely linked to the surrounding society as commercial buildings have several economic, environmental, political, social and cultural influences. [3] Toivonen and Viitanen (2015) also opined that, forces of demand and supply plays a role in shaping the future of commercial property market. Many important indicators, such as demand, supply, vacancy rates, absorption volume, proposed projects, as well as economic indicators, legal and tax matters are being included in the regular property market overviews of the leading property companies (like "CBRE", "Colliers International", "Newsec"[4],[5] (Colliers International, 


\section{International Journal of Engineering Applied Sciences and Technology, 2020 \\ Vol. 5, Issue 2, ISSN No. 2455-2143, Pages 609-615 \\ Published Online June 2020 in IJEAST (http://www.ijeast.com)}

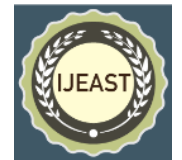

2015),(CRBE,2015). These overviews are useful for understanding of many property markets, including the commercial property market [6] (Colliers International, 2016).

The data collection on the demands and prevailing market trends are significant in construction and property development industries. Proper market research may help to understand the market needs [7] (Alhammadi, Algahtany, Kashiwagi, \& Sullivan, 2016). The commercial property market indicators, such as forces of demand and supply, availability of land resources, capital, and man power and construction procedures in Nigeria are reviewed in further sections of this paper. All these factors are significant for local Nigerian developers as well as for international companies, international construction companies and international developers, which are entering the Nigerian property market. The commercial property in Nigerian property market is gaining ground due to its demand on daily bases especially when the property is situated and located in good and strategic location. Not only that, commercial property with sophisticated facility and infrastructure will always attract investors and this increases demand for commercial property, When such trends are based on rental values then the observation will be confined to any evident changes in rent patterns. Rents or sales passing on properties are bound to be influenced due to the heterogeneity nature of real estate. These factors range from intrinsic to extrinsic characteristics [8] (Iroham, Oluwumi, Simon and Akerele, 2014). They include closeness to high-rise office buildings [9] (Thibodeau, 1990); accessibility [10] (Ball, Lizieri and MacGregor, 1998); location, size, structural characteristics [11],[12] (Tay, Lau and Leung, 1999; McCluskey, Deddis, Lamont, \& Borst, 2000); proximity to rail and park [13] (Jensen and Durham, 2003); provision of balconies [14] (Chau, Wong, , and Yiu, 2004); proximity to open space [15] (Anderson and West, 2005); location of dams [16] (Provencher, Sarakinos, and Meyer,. 2006); it is indisputable truth that that the provision of the following as mention above is the basic ingredient that will present commercial property physically feasible and economically viable.

\section{STATEMENT OF PROBLEM}

One of the basic need of man is housing, be it for residen tial, commercial, institutional, or agricultural purposes, nevertheless the solution to this social problem is challenged by some factors like poverty, crime, unemployment, population gr owth, lack of infrastructure, unfavorable government policies, and abuse of professionalism etc. the effect of location on commercial property values has created a great concern as the disadvantaged commercial property are gradually losing their relevance, if not going into extinction. This study observed recently, that upon construction of new commercial properties in Ontisha main market, properties located along transport route are on high demand that the demand of such property is two times higher than the supply especially when it is located on a road side. Again we discovered that upon entering inside the market proper, there were vacant shops, offices, and warehouses to be let. Consequently the completion of new commercial properties are now rendering the old once into physical, functional, and economical deterioration and obsolescence. Not minding that these properties can be fixe to principle of highest and best use.

\section{AIM OF THE STUDY}

The aim of the study is to appraise the effect of location on property value of commercial properties in (Onitsha main market) Onitsha north local government anambra state.

\section{OBJECTIVES OF THE STUDY \\ i. To determine the effect of location on property values \\ ii. To ascertain the reason investors chooses a particular location for investment in (Onitsha main market) Onitsha north local government anambra state. \\ iii. To recommend a constructive approach in solving the problem silently with effective results.}

\section{SIGNIFICANCE OF STUDY}

The study contributes to existing knowledge on method of preserving commercial property investment in real estate in Nigeria as well as solution for some location problems in real estate practice. Having addressed these salient and age long challenges to real estate development in Onitsha main market, Onitsha north local government anambra state. The proffered solution should now set a road map developed to open unlimited opportunity for investors without jeopardizing or risking their investment unnecessarily. These will lead to increase in provision of commercial building to care for the growing need of a developing economy and equally provide decent commercial accommodation as engine of economic growth and national development. Furthermore a critical observance and execution of the solution provided in this study will ameliorate the persistence Search for newer location and enhance the culture of urban renewal and sustainability. 


\section{LITREATURE REVIEW THEORETICAL FRAMEWORK}

The Cambridge dictionary, defined commercial property as "a building or land that is use for business" it is also define as real estate approved and designed for retail or wholesale trade, hotel, restaurant, offices, clinics, shopping malls, stores, warehouses, light manufacturing, and other such uses but not for residential purposes. Also called commercial facility. [17], [18] (Kuye,2003),(James, 2018), suggested that the term "commercial property" is too elaborate to be define, however he said that commercial property refers to real estate property that is used for business activities. Commercial property usually refers to buildings that house businesses, but it can also refer to land that is intended to generate a profit, as well as larger residential rental properties. The designation of a property as a commercial property has implications on the financing of the building, the tax treatment and the laws that apply to it. [19] (Udechukwu, 2006), offices [20] (Nwachukwuand Emoh,2013), warehouse/industry [21] (Udechukwu and Johnson, 2008), shopping malls, they agreed that commercial properties exist in types and classifications. That notwithstanding [22] (Ezgi, Seda, and Tahsin, 2015) opined that to assess the value of land by evaluating several factors, related to a real estate, e.g. location, environment, topography, utilization conditions etc. is called real estate valuation, which is a key factor for land management. [23], [24] (Okeke, 2009),(Hoyt,1939) and [25] (Burgess,1925) insisted, that location has tremendous impact on development and property value. Moving along bridge headSokoto line, bright street-Iweka road, and Emeka ofor plaza- new and old market road all in main market, construction of commercial properties is sprawling with speed along major transportation route.

\section{OVERVIEW OF COMMERCIAL REAL ESTATE MARKET}

According to un-habitat and world economic forum, the composition of real estate market is designed in such a way they function on the dependency of various variable that always give birth to forces of demand and supply[26],[27] (UN-Habitat, 2012; WEF,2016). However, [28] Igbnosa (2011), added that, the characteristics of the building and estate market values in any given area is determinant on property value while [29] Emenike (2020), [30](James and
Murungi,2015) insist that the only factor that will guarantee success of any property value is the availability of real estate infrastructure.

There are number of factors and stages of development process that should be considered by the property developer, if it must achieve its feasibility and viability objectives these factors includes economy, property cycles and markets, government policy and strategy, legislation, as well as environment, population, politics, transport, technology, etc. All these factors can significantly affect the feasibility and viability progress of the development project, thus ultimately affecting profitability.

\section{THE STUDY AREA}

Onitsha is located in Anambra State, which is one of Nigeria's 36 states and one of 5 states in the country's south-east geo-political zone. The other states in the zone are Abia, Ebonyi, Enugu, and Imo. The new Anambra State was created in August 1991, together with Enugu State from the old Anambra State, with its state capital at Awka. The state is divided into 21 local

government areas for administrative purposes, each with its headquarters. Onitsha is the gateway to eastern Nigeria and economic enrolment for business activity. Onitsha is located on latitude $6.1^{\circ} \mathrm{N}$ and longitude $6.8^{\circ} \mathrm{E}$ in the Anambra North Senatorial Zone of Anambra State. It occupies the eastern bank of the Niger River, covering some 50 square kilometers. Onitsha is strategically located and accessed through the east-west national main road from Lagos through Benin, which links the eastern north-south route via the Niger Bridge at Onitsha. The main concentration

of population and industrial activity and the areas showing the greatest potential for growth are situated along this transportation axis. The recent process of urban expansion largely reflects the communication network. Onitsha's location, which combines both road and waterway access points, this feature makes it one of the four main potential industrial and commercial growth areas in Nigeria. The city is split into two local government areas, Onitsha South and Onitsha North. Both areas are bound by Ogbaru local government to the south, Idemili North and Oyi to the east, and Anambra East to the north. With about twenty eight market making Onitsha a city with the highest number of market in south east geo-political zone of Nigeria. 


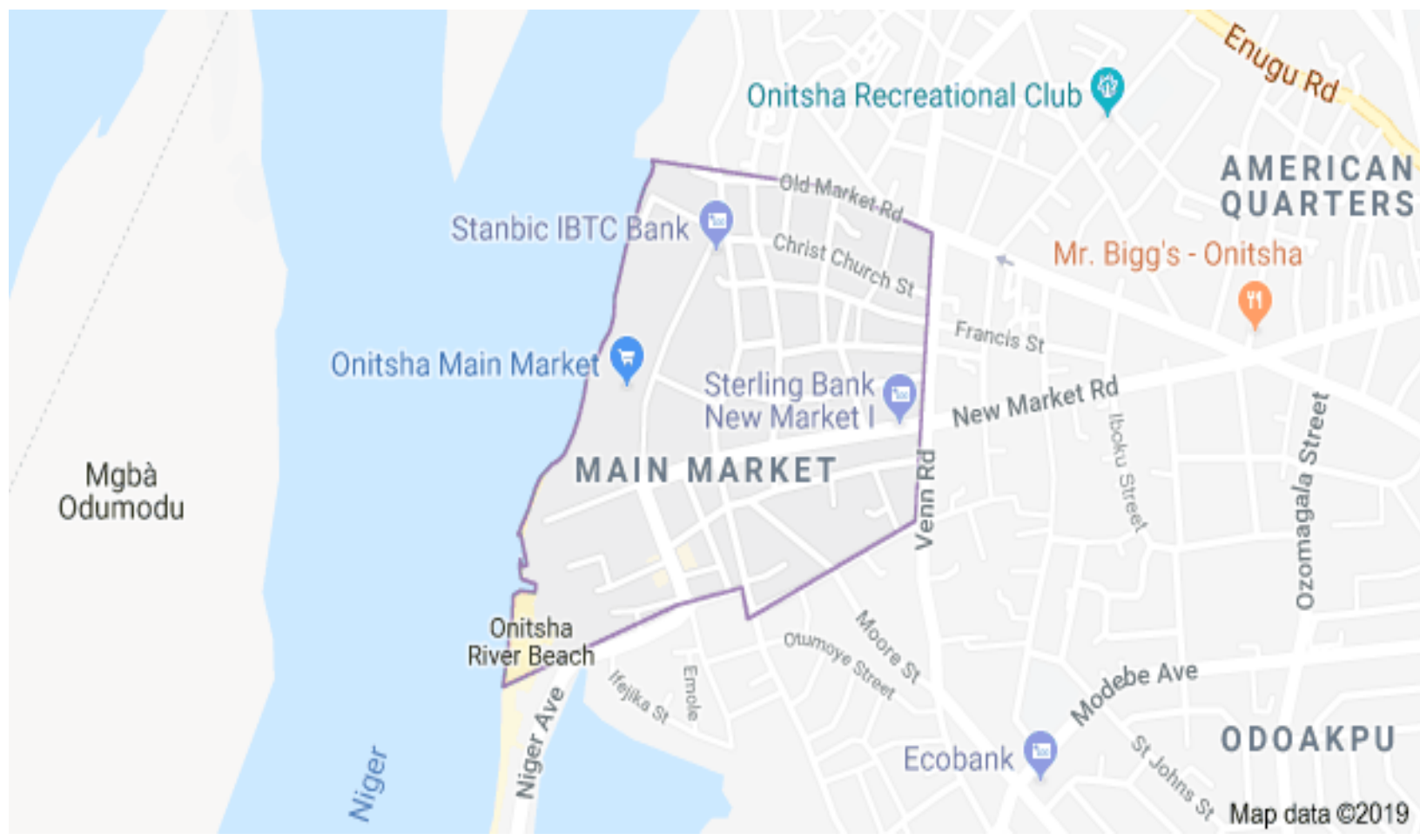

Fig.3.2. map showing Onitsha main market (source. goggle earth map).

\section{RESEARCH METHOD}

Data for this study was sourced from both primary and secondary sources. While the primary data was generated through questionnaire which was drafted and distributed to (40) commercial property owners, (90) commercial property occupiers and (20) estate surveyors and valuers, as relevant stake holders in Nigeria real estate commercial property market and observations by the researcher, $120(87 \%)$ was retrieved and used for the study. The secondary sources of data were sourced from written materials such as journals, conference papers, textbooks and mimeographs where used for this study. Data were presented with tables while percentages, arithmetic mean and relative importance index(RII) were used to determine the level of significance of the factors.

\section{POPULATION}

The population for this research study comprises of commercial property owners and occupiers, in Onitsha main market, Onitsha north local government anambra state. and estate surveyors and valuers in the study area.

\section{SAMPLING SIZE}

For the purpose of this research study, the simple random sampling approach was used. Thus the sample size of the study is 120 respondents, thirty five (35) commercial property owners, seventy five (75) commercial property occupiers and ten (10) estate surveyor and valuer. Since it is not easy to distribute questionnaire to everybody concerned, the use percentage for research population is considered to be accurate.

\section{RESULT AND DISCUSSION \\ $\underline{\text { Section }=A \text {; Socio-demographic of the respondents }}$}

Table 4.1: Age Distribution, Academic qualification and commercial property type of use, of the Respondents

\begin{tabular}{|c|c|c|c|c|c|c|c|c|}
\hline & $\begin{array}{c}\text { Frequency } \\
\text { Age (Y) }\end{array}$ & Percentage (\%) of (F) & $\begin{array}{c}\text { Academic } \\
\text { qualification }\end{array}$ & $(\mathbf{F})$ & $\begin{array}{c}(\%) \text { of } \\
(\mathbf{F})\end{array}$ & $\begin{array}{c}\text { Property } \\
\text { type }\end{array}$ & $\begin{array}{c}(\mathbf{F}) \\
(\%) \text { of } \\
(\mathbf{F})\end{array}$ \\
\hline
\end{tabular}




\begin{tabular}{|c|c|c|c|c|c|c|c|c|}
\hline $21-30$ & 28 & 23 & FLSC & 68 & 57 & Office & 32 & 27 \\
$31-40$ & 60 & 50 & SSCE/OND & 35 & 29 & Shop & 69 & 57 \\
$41-50$ & 20 & 17 & HND/BSc & 17 & 14 & Hall & 19 & 16 \\
$51-60$ & 12 & 10 & Total & 120 & 100 & Total & 120 & 100 \\
Total & 120 & 100 & & & & & & \\
\hline
\end{tabular}

girls/boys, I.T students and ad-hoc staff having obtain either SSCE or OND, and 17\% who are graduate working

From table 4.1 above, $23 \%$ of the respondents are between the age brackets of 21-30 years, $50 \%$ are within $31-40$ years, $17 \%$ are within 41 -

50 years, and $10 \%$ are within $51-60$ years respectively. This indicates that majority of the respondents (90\%) belongs to labor force and their decisions have effect on location of commercial properties in the study area. From the academic qualification row and column it is obvious that $57 \%$ of respondents are traders that join business after obtaining their FLSC, while $29 \%$ are working with different business organizations either as staff, sales in some establishment like banks insurance, stock, and estate brokers telecom companies etc. as full staffs while others are business executives. The study also reveals that the level of literacy is competing very high at $46 \%$ over what is use to be in previous years. Again, the commercial property in use, in the study area ranges from shops 57\%, office $27 \%$, and hall $16 \%$. Which also indicate that the difference in demand for shop is 53\% to compare with office which is $47 \%$. We also observed that halls are not in much demand since many occupiers convert two or more shops to office and banks prefer owning their business property

Table 4.2: Occupation, Ownership Status and duration of occupancy (D.O) of the Respondents

\begin{tabular}{|c|c|c|c|c|c|c|c|c|}
\hline Occupation & $(\mathbf{F})$ & $(\boldsymbol{\%}) \mathbf{o f}(\mathbf{F})$ & $\begin{array}{c}\text { Ownership } \\
\text { Status }\end{array}$ & $(\mathbf{F})$ & $(\boldsymbol{\%})$ of $(\mathbf{F})$ & D.O & $(\mathbf{F})$ & $\begin{array}{c}(\%) \text { of } \\
(\mathbf{F})\end{array}$ \\
\hline Traders & 57 & 47 & Sub Lease & 50 & 42 & $1-10$ & 53 & 44 \\
\hline Craftsmen & 15 & 13 & Lease & 56 & 47 & $20-30$ & 55 & 46 \\
\hline Civil Servant & 48 & 40 & Land-lord & 14 & 11 & $30-$-above & 12 & 10 \\
\hline TOTAL & 120 & 100 & TOTAL & 120 & 100 & TOTAL & 120 & 100 \\
\hline
\end{tabular}

From table 4.2 above, the occupation of respondents in the study ranges from traders $47 \%$, civil servants $40 \%$, and craftsmen $13 \%$, which also reveals that there are other commercial activity moving on in the study area at a difference of $15 \%$ this activities include banking, insurance firms, estate surveyors and valuers, barristers and solicitors, clearing agents, transport companies, telecommunication companies, servicing firms, information communication technologies firms, oil and gas companies etc. on the next row and column is ownership status, most of the commercial property occupiers in the study area are on lease hold $47 \%$ and sub lease hold $42 \%$ and owner occupiers are $11 \%$. On the row and column of duration of occupancy, its easily notice that $(90 \%)$ of the respondents are on a steady transition in which their movement either horizontal or vertical has effect because, they change location which also have positive or negative effect on property. 
International Journal of Engineering Applied Sciences and Technology, 2020

Vol. 5, Issue 2, ISSN No. 2455-2143, Pages 609-615

Published Online June 2020 in IJEAST (http://www.ijeast.com)

Section = B; Location, Infrastructural, Structural and Economic Factors Affecting Commercial Property in the Study Area.

\begin{tabular}{|c|l|l|l|l|l|l|c|}
\hline No & Factors & A & B & C & D & TOTAL & RII \\
\hline 1 & Location impact (traffic, topography, highway) & 56 & 34 & 51 & 71 & 212 & 1.766 \\
\hline 2 & Infrastructural (road network, electricity, security) & 92 & 103 & 32 & 21 & 248 & 2.066 \\
\hline 3 & Structural (modern building, management, facility) & 56 & 86 & 43 & 26 & 211 & 1.758 \\
\hline 4 & Economic (rent, size, population, demand) & 25 & 51 & 96 & 98 & 219 & 2.250 \\
\hline
\end{tabular}

\section{CONCLUSION}

Investigation were made as regards the opinion of respondents on whether the stake holders considers the influence of factors such as locational, infrastructural, structural, and economic factors, have on the value of commercial properties in the study area. Results showed that majority of the stake holders are of the opinion that locational, infrastructural, structural, and economic factors, actually affect property value and as against location only as 122 (RII: 1.766) gave disapproval. Furthermore the table agrees with our field observation that lack of infrastructure like standard motor parks, road network (RII2.066) that was formerly built have dilapidated, lack of power supply, poor/dilapidated facility together with poor management as in (RII1.758). To our greatest surprise rent at the inside market where found to be lesser than that of the road side, that is the reason the respondents insist that size and rent of the property is not the major factor that determine commercial property value in the study area as in (RII 2.550)

The government and market traders union should partner with professionals like estate surveyors and valuers, town planer architects builder and engineers etc., on modern approach of urban renewal and sustainability. There is the need for government to harness redevelopment plan within the study area to create a platform for providing infrastructure and systematically attracting investors inside the market through it fiscal policies. The recommendation provided in this study will strike a balance in values of commercial properties and create a road map for good property investment in Nigeria.

Acknowledgements

I wish to acknowledge the contributions of everyone, especially authors and publishers, whose works were consulted during the execution of this study and others who contributed directly or indirectly to the success of this work. We appreciate you all.

\section{REFRENCES}

[1] Okeke G. C., (2009); Urban Land use Economics I Mimeograph Department of Estate

Management, Federal Polytechnic Oko (pp. 17-31).

[2] Toivonen, S., and Viitanen, K. (2015). Forces of Change Shaping the Future Commercial Real Estate Market in the Helsinki Metropolitan Area in Finland. Land Use Policy, 42, 471-478

[3] Toivonen, S., and Viitanen, K. (2016). Environmental Scanning and Futures Wheels as Tools to Analyze the Possible Future Themes of the Commercial Real Estate Market. Land Use Policy, 52, 51-61. http://dx.doi.org/10.1016/j.landusepol.2015.12.011

http://dx.doi.org/10.1016/j.landusepol.2014.09.004

[4] CBRE. (2015). Market review. Baltics Investment (March 2015). Retrieved from CBRE website: http://www.cbre.lv/lv_en/research Covenant Journal of Research in the Built Environment (CJRBE) Vol. 1, No. 1 (Maiden Edition), January.

[5] Colliers International. (2016). Real Estate Market Overview. Annual Review. Latvia. Lithuania.

Estonia. Retrieved from

http://www.colliers.com/-/lv-lv/latvia/insights/researchthe-market

[6] Colliers International. (2015). Real Estate Market Overview. Annual Report. Latvia. Lithuania. Estonia.

Retrieved from

http://www.colliers.com/lv-lv/latvia/insights/researchthe-market

[7] Alhammadi, Y., Algahtany, M., Kashiwagi, D., Sullivan, K., and Kashiwagi, J. (2016). The Current State of Research and Development Approach ( $\mathrm{R}$ and D) in the Saudi Construction Industry. Procedia Engineering, 145, 1462-1469. Retrieved from CBRE website:

http://dx.doi.org/10.1016/j.proeng.2016.04.184

[8] Iroham, C.O., Oluwumi, A.O., Simon, R.F., and Akerele, B.A., (2014). Assessing the Trend in Rental Values Of Commercial Properties Along Oyemekun Road, Akure, Nigeria. Covenant Journal of Research in the Built Environment (CJBE) Vol.1, No.1, (Maiden Edition). January. (Pp.10-29). 


\section{International Journal of Engineering Applied Sciences and Technology, 2020 \\ Vol. 5, Issue 2, ISSN No. 2455-2143, Pages 609-615 \\ Published Online June 2020 in IJEAST (http://www.ijeast.com)}

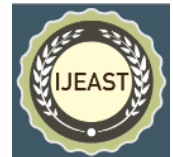

[9] Thibodeau, T.G., (1990) Estimating the Effect of High Rise Office Buildings on Residential Property Values, Land Economics, 66(4), 402-408.

10] Ball, M.; Lizieri, C., and MacGregor, B. D. (1998). The Economics of Commercial Property

Markets, Routledge, 402 pp., ISBN 0-415$14992-4$

[11] Tay, R. S., Lau, C. K. and Leung, M. S. (1999).

The Determination of Rent in Shopping Centers: Some

Evidence from Hong Kong, Journal of Real Estate

Literature, 7(2), 183-196 Agricultural \& Applied

Economics Staff Paper Series.

[12] McCluskey, W.J., Deddis, W.G., Lamont, I.G., and

Borst, R.A. (2000). "The Application of Surface

Generated interpolation Models for the Prediction of

Residential Property Values. Journal of Property Investment \& Finance, 18(2), 162-176.

[13] Jensen, D., and Durham, J. (2003). The Property

Value Effects of the South Ridgeline rail.

Retrieved from:

http://economics.uoregon.edu/honors-

papers/2003/Ridgeline\%20paper.pdf on February 2,

[14] Chau, K. W., Wong, S.K., and Yiu, C.Y. (2004)

the Value of the Provision of a Balcony in Apartments

in Hong Kong. Property Management, 22(3), 250-264.

Retrieved

from:

http://doi.org/10.1108/026370410545020

[15] Anderson, S.T., and West, S.E. (2005). Open Space, Residential Property Values, and Spatial Context. Regional Science and Urban Economics, 36(6), 773-789.

[16] Provencher, B., Sarakinos, H., and Meyer, T. (2006). Does Small Dam Removal Affect Local Property Values? An Empirical Analysis, University of Wisconsin-Madison

[17] Olusegun, G. K., (2003). Principles and Practice of Property Valuation, General Principles', Climax Communications Limited, Lagos.

[18] James, C. (2018). Alternative investment in real estate commercial properties

Retrieved from:

https://www.investopedia.com/terms/c/commercial-

property.asp

[19] Udechukwu, C.E., (2006); Principle of Valuation

Treem Nigeria Ltd Lagos

[20] Nwachukwu, C.C., and Emoh, F.I (2013). Industrial Location Decision and its Impact on Project Success: the need for a professional guide. Journal of the Nigeria Institution of estate surveyors and valuers, volume 38, No. 1, 2013 January-June.

[21] Udechukwu, C.E., \& Olusola, J. (2008). Principle of Valuation Treem Nigeria Ltd Lagos

[22] Ezgi, C., Seda, B.K., \& Tahsin Y. (2015). Determining the Factors Affecting Housing Prices FIG Working Week 2015.
[23] Okeke G. C., (2010); Urban Land use Economics II Mimeograph Department of Estate Management, Federal Polytechnic Oko (pp. 32-41).

[24] Hoyt, H., (1939). The Structure and Growth of Residential Neighborhood in American Cities. Federal Housing Administration.

[25] Burgess, E.W., (1925). The Growth of the City in Park, R. E. et al. the City. University of Chicago Press. [26] UN-Habitat. (2012). Nigeria: Onitsha Urban Profile Countries. Available at: www.unhabitat.org/publications/ (accessed on 19/06/2019).

[27] World Economic Forum. (2016). Competitiveness Rankings 2015-2016. Retrieved from http://reports.weforum.org/globalcompetitiveness-report-2015-2016/competitivenessrankings/

[28]Igbinosa, S.O., (2011). Determinant of Residential Property Value in Nigeria- A Neural Network Approach. International Multidisciplinary Journal, Ethiopia. Vol.5, (5) serial No.2, October. http://dx.doi.org./10.4314/afrrev.v5i5.13

[29] Emenike, K.C., (2020). Alternative Measure in Providing Real Estate Infrastructure in a Recess Economy in Awka, Anambra State Nigeria, International Journal of Engineering Applied Sciences and Technology, 2020

Vol. 4, Issue 11, ISSN No. 2455-2143, (pp. 28-33).

Available at: http://www.ijeast.com

[30] James, M.G., and Murungi, M.M., (2015). Infrastructure Development and Real Estate Value in Meru County, Kenya. Research journal of accounting. Vol.6, No.8, (pp. 212-221).

Available at: www.iiste.org

[31] www.Investopedia.com

[32] www.ecb.europe.eu

[33] www.wikipedia.com

[34] www.nairaland.com

[35] www.businessdirectory.com

[36] www.goggleeart map.com 